\title{
Efficacy and Safety of Glucocorticoids Therapy for IgA Nephropathy: A Meta- Analysis of Randomized Controlled Trials
}

\author{
Jun Cheng $^{\mathrm{a}}$ Xiaohui Zhang ${ }^{\mathrm{a}}$ Wen Zhang $^{\mathrm{b}}$ Qiang He $^{\mathrm{a}}$ Xiaojuan Tao ${ }^{\mathrm{b}}$ \\ Jianghua Chen ${ }^{\mathrm{a}}$ \\ ${ }^{a}$ Kidney Disease Center, First Affiliated Hospital, Medical School, Zhejiang University, and \\ ${ }^{b}$ Department of Nephrology, Hangzhou Red Cross Hospital, Hangzhou, PR China
}

\section{Key Words}

Glucocorticoids $\cdot \lg A$ nephropathy

\begin{abstract}
Background: Published reports examining the efficacy and safety of glucocorticoids for preserving renal function in immunoglobulin A nephropathy (IgAN) have yielded conflicting results. To systematically evaluate the efficacy and safety of glucocorticoids agents for IgAN, we conducted a metaanalysis of the published randomized controlled trials (RCTs). Methods: MEDLINE, EMBASE, the Cochrane Library and article reference lists were searched for RCTs that compared glucocorticoids with placebo and any other non-immunosuppressive agents for treating IgAN. The quality of the studies was evaluated with the method of the intention-to-treat analysis and allocation concealment, as well as with the Jadad method. Meta-analyses were performed on the outcomes of proteinuria and renal survival and adverse events in patients with IgAN. Results: Seven RCTs involving 386 patients were included in the review. Four RCTs reported renal survival data with Kaplan-Meier survival curves. Overall, glucocorticoid agents had statistically significant effects on improved renal survival (HR $0.20,95 \% \mathrm{Cl} 0.20$ to 0.39 ) and reduction of proteinuria (standardized mean difference SMD, $-0.51 ; 95 \% \mathrm{Cl}-0.73$ to -0.29 ) when compared with the con-
\end{abstract}

trol group. Tests for heterogeneity showed no difference in effect among the studies. In general, glucocorticoid agents were well tolerated. Patients receiving glucocorticoids therapy did not have an increased risk of development of type 2 diabetes mellitus, hypertension or Cushingoid adverse effects, while glucocorticoids were associated with a significant increase in the risk of gastrointestinal tract adverse events. Conclusions: The current cumulative evidence suggests that glucocorticoids have statistically significant effects on protecting renal function and reduction of proteinuria in patients with $\operatorname{lgAN}$, but we should be careful for its gastrointestinal tract reaction. In general, glucocorticoids agents are a promising medication and should be investigated further.

Copyright $\odot 2009$ S. Karger AG, Basel

\section{Introduction}

Immunoglobulin A nephropathy (IgAN) was first reported in 1968 by Dr J. Berger [1]. It is now generally known to be the most common form of primary glomerulonephritis throughout the world [2-4]. IgAN was ini-

\section{J. Cheng and X. Zhang contributed equally to this work.}

\section{KARGER}

Fax +4161306 1234 E-Mail karger@karger.ch www.karger.com
Prof. Jianghua Chen

Kidney Disease Center, The First Affiliated Hospital

College of Medicine, Zhejiang University

Qingchun Road 79, Hangzhou 310003 (PR China)

Tel. +86 5718723 6992, Fax +86 5718723 6189, E-Mail chenjianghua@zju.edu.cn 
tially thought to be a rare and benign cause of recurrent hematuria, however, it is actually neither rare nor benign. It has been demonstrated that IgAN is a worldwide disease that progresses to end-stage renal disease (ESRD) in up to $15-20 \%$ of affected patients within 10 years from the apparent onset of disease and in up to $30-40 \%$ of individuals within 20 years from diagnosis $[5,6]$. The mechanisms involved in the pathogenesis of this disease have remained unclear. Therefore, many treatment approaches have been attempted in the past 2 decades; however, no specific treatment has been established and there are wide variations in current practice [7-9].

The most commonly used regimens include immunosuppressive agents such as glucocorticoids, cyclosporin A or cyclophosphamide, and nonimmunosuppressive medications including fish oils, anticoagulants, antihypertensive agents and surgical tonsillectomy, which have been tested in a variety of studies including randomized controlled trials (RCTs). Numerous RCTs with glucocorticoid therapy for IgAN have been published, the expected outcome of treatment is slowing the deterioration of renal function, as well as a reduction in daily proteinuria, with few adverse events. However, published reports examining the efficacy and safety for preserving renal function and reduction of proteinuria in IgAN have yielded conflicting results.

Therefore, we present the results of a systematic review summarizing currently available evidence from RCTs pertaining to the effect of glucocorticoids for the treatment of IgA nephropathy.

\section{Materials and Methods}

\section{Inclusion Criteria}

To be selected for analysis, a study had to meet all of the following criteria: (i) the study was an RCT; (ii) the study compared glucocorticoid agents (any dose, type) versus placebo/no treatment; (iii) glucocorticoid agents (any dose, type) versus any other non-immunosuppressive agents; (iv) the first period of available randomized, cross-over studies shall be included. Studies with any other immunosuppressive agents, such as cytotoxic agents or mycophenolate mofetil, in only one arm, were excluded.

\section{Search Strategy}

Electronic searches were performed using MEDLINE (1966 to 2008) and EMBASE (1988 to 2008); the Cochrane Controlled Trials Register (CCTR; Specialized Renal Registry) available on compact disk was also searched. The following medical subject heading terms and text words were used: glomerulonephritis, $\operatorname{Ig} \mathrm{A}, \operatorname{Ig} \mathrm{A}$ nephropathy, immunoglobulin A nephropathy, and Berger disease, steroid, prednisone, glucocorticoids, proteinuria, randomized controlled trials, clinical trials. Reference lists from identi- fied articles were also searched. The titles and abstracts of the articles were analyzed by two of the authors (Jun Cheng, Wen Zhang) independently to ascertain conformity with the inclusion criteria. The full text of an article was reviewed carefully if the screening of its title and abstract was unclear as to its admissibility.

Study Validity Assessment

We evaluated the quality of the studies in terms of allocation concealment and intention-to-treat analysis, blinding of investigators, participants and outcome assessors, and completeness to follow up, as well as the Jadad scale [10-12].

The Jadad scale is an established procedure by which study methodologies are evaluated. Its scale assigns 0 or 1 points to each of the following 5 items: (i) with or without randomization; (ii) with or without a double-blind design; (iii) the appropriateness of the randomization methods if used; (iv) the appropriateness of double-blinding design if used; (v) the analysis and reasons for withdrawals and dropouts. Thus, the Jadad scores can range from 0 to 5 . The quality of studies to be included was assessed independently by 2 reviewers. A priori, it was decided that studies should be scored as excellent quality if they received a Jadad score of 5 (of a possible 5 points), good quality if the score was 3 or 4 , and poor quality if the score was $\leq 2$.

\section{Data Extraction}

Data extraction was performed on full-text copies of all included trials by the 2 reviewers independently, using data extraction forms developed for this purpose. Data were extracted from all included trials in terms of patient characteristics of the study sample, the study drugs, doses, baseline characteristics of the trials, follow-up and lost at follow-up (\%) and the following reported outcomes: (i) the primary outcome was renal survival (defined by impairment of renal function reaching doubling of serum creatinine or/and reaching ESRD requiring dialysis therapy or transplantation at any time during treatment), with the log-rank $p$ value of renal survival analyzed by means of the Kaplan-Meier method; (ii) the secondary outcome was daily proteinuria $(\mathrm{g} / 24 \mathrm{~h})$ at the end of treatment (measured from timed urine specimens for proteinuria and albuminuria and spot urine specimens (protein to creatinine or albumin to creatinine ratio) and converted to grams per $24 \mathrm{~h} \mathrm{[13]);} \mathrm{(iii)} \mathrm{adverse} \mathrm{events} \mathrm{of} \mathrm{treatment.}$

Any additional information required from the original investigators was requested by written correspondence, and if relevant information was obtained in this manner, that was included in the review. If an outcome was reported at more than one time point for a single study, the longest period of follow-up was used.

\section{Statistical Analysis}

Dichotomous outcome data from individual trials were analyzed by using the relative risk (RR) measure. For continuous outcomes, the difference in means and their $95 \%$ confidence interval (CI) at the end of treatment were calculated for individual trials, and the SMD was used as a summary estimator.

Renal survival was data of time to events. Because it has been suggested that the use of the odds ratio (OR) and RR to analyze survival data might be inappropriate [14], the hazard ratio (HR) was used as a summary estimator. Unfortunately, few articles report HR for survival outcomes. Therefore, the methods of Parmar [14] were used to estimate the HR from the observed numbers of 
Fig. 1. Flow diagram of studies considered for inclusion. Results of a systematic literature search on glucocorticoids treatment for IgA nephropathy.

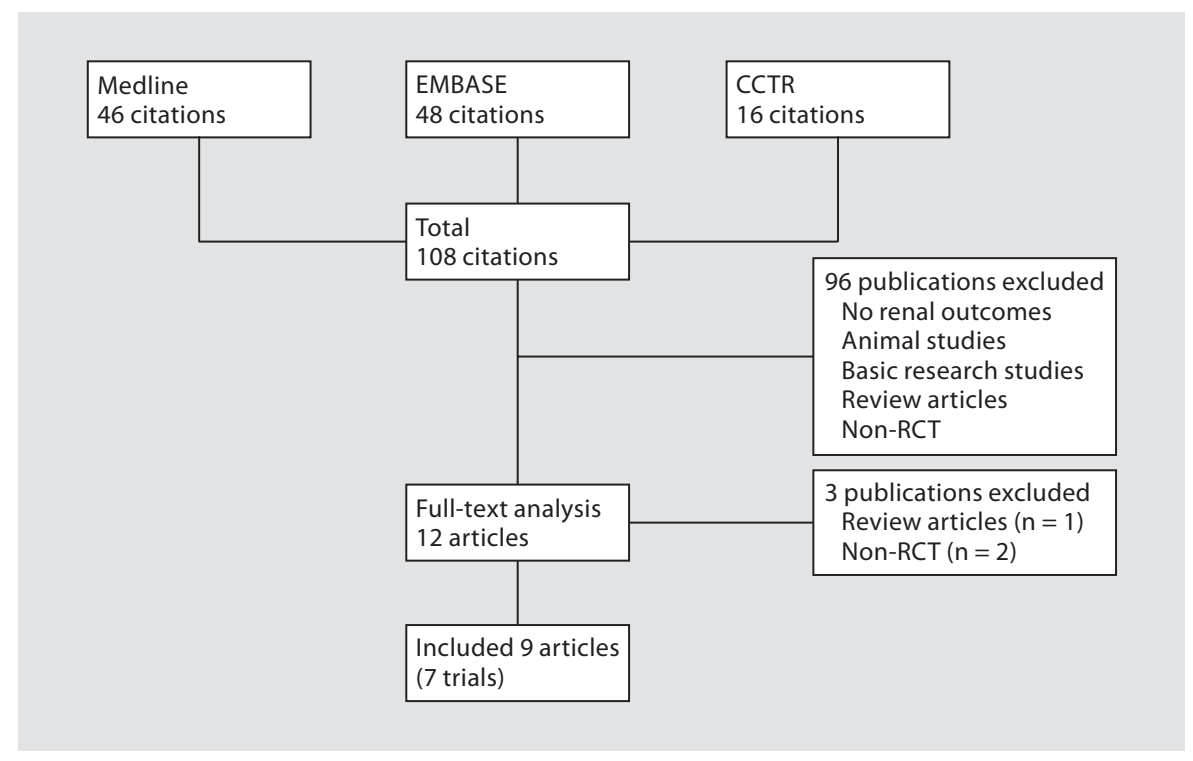

events and the log-rank statistic for the difference between Kaplan-Meier survival curves when reported. All summary effects are presented with a $95 \% \mathrm{CI}$.

The fixed-effect model weighted by the Mantel-Haenszel method was used, followed by a test of homogeneity [15]. Heterogeneity was analyzed using a $\chi^{2}$ test on $\mathrm{N}-1$ degrees of freedom. A $p$ value of 0.05 was regarded as the critical value for homogeneity [16]. If the hypothesis of homogeneity was rejected ( $p$ value $<0.05$ ), the random effect model using the DerSimonian-Laird method was employed [17].

Funnel plots and Begg's test were used to probe for publication bias. Forest plots were used for graphic representation of data. The vertical lines in these plots - positioned at 1 , for $\mathrm{RR}$ - represent equivalence in efficacy between the experimental and control treatments. Trials to the left of that line showed a reduction in risk with the experimental intervention, those to the right showed an increase in risk with the experimental intervention. A solid square and horizontal line represent the RR with 95\% CI, respectively. The surface area of the black square represents the relative quantitative contribution of the trial to the analysis (weight). The horizontal line indicates the $95 \% \mathrm{CI}$. The diamond-shaped symbol is the summary estimate of effect expressed as an RR with 95\% CI, which is a weighted average of the pooled treatment effects across all trials. A p value $<0.05$ was considered statistically significant.

In our analysis, all glucocorticoids were combined regardless of dosages with an assumed class effect and analyzed regardless of the types of controls.

To determine the robustness of our pooled effects, we compared our primary analysis with fixed effects and random effects models. Pooled estimates were also recalculated after excluding RCTs whose quality was poor (Sum of Jadad score $<3$ ). All statistical analyses were performed using Review Manager 4.2 statistical software for the meta-analysis.

Glucocorticoids Therapy for IgA Nephropathy

\section{Results}

\section{Trial Flow and Study Characteristics}

The combined search of MEDLINE, EMBASE, and CCTR, which also included some hand-searching of relevant nephrology journals, retrieved 107 citations. After discarding a number of duplicates retrieved by individual searches and reviewing all titles and abstracts, 98 studies were excluded because they were not RCTs, or were not meant to investigate any of the outcomes of interest to this study, or were animal or basic research studies or review articles. Thirteen articles were reviewed in full text to further assess their eligibility; one review was excluded. Two quasi-randomized controlled trials publications also were excluded. Overall, 7 trials (9 publications) [18-24], enrolling a total of 386 patients, were included in this analysis (fig. 1).

The details of interventions, baseline characteristics of populations, study period, concomitant drugs, follow up, lost during follow-up (\%) and outcomes of renal function in the RCTs included in our analysis are summarized in table 1 .

\section{Quality Assessment}

A quality assessment of the primary studies is summarized in table 2. The Jadad scores ranged from 0 to 5 points. Study quality on the whole was poor; 5 of 7 studies had a Jadad score of $\geq 3$, and 2 of 7 had a Jadad score of $\leq 2$. Participants and investigators were blinded in only 1 of 7 trials, sufficient details of drop-outs and with- 
Table 1. Characteristics of interventions and populations at baseline and end of treatment in included RCTs

\begin{tabular}{|c|c|c|c|c|c|c|c|c|}
\hline \multirow[t]{2}{*}{ RCTs } & \multicolumn{2}{|l|}{ Drugs } & \multirow[t]{2}{*}{ Baseline characteristics } & \multirow{2}{*}{$\begin{array}{l}\text { Follow- } \\
\text { up } \\
\text { months }\end{array}$} & \multicolumn{2}{|c|}{ Treatment group } & \multicolumn{2}{|c|}{ Control group } \\
\hline & treatment group & $\begin{array}{l}\text { control } \\
\text { group }\end{array}$ & & & $\begin{array}{l}\text { sample } \\
\text { sizes }\end{array}$ & $\begin{array}{l}\mathrm{DRF} / \\
\mathrm{UH}\end{array}$ & $\begin{array}{l}\text { sample } \\
\text { sizes }\end{array}$ & $\begin{array}{l}\mathrm{DRF} / \\
\mathrm{UH}\end{array}$ \\
\hline $\begin{array}{l}\mathrm{Lv} \\
2009\end{array}$ & $\begin{array}{l}\text { Prednisone } 0.8 \text { to } 1.0 \mathrm{mg} / \mathrm{kg} / \text { day } \\
\text { for } 8 \text { weeks, then the dose was } \\
\text { tapered by } 5 \text { to } 10 \mathrm{mg} \text { every } 2 \text { weeks; } \\
\text { plus cilazapril }\end{array}$ & $\begin{array}{l}\text { Cilazapril } \\
\text { alone }\end{array}$ & $\begin{array}{l}\text { Age of } 18 \text { to } 65 \text { years, urine protein } \\
\text { excretion of } 1 \text { to } 5 \mathrm{~g} / \text { day; eGFR }>30 \\
\mathrm{ml} / \mathrm{min}\end{array}$ & 28 & 33 & 1 & 30 & 7 \\
\hline $\begin{array}{l}\text { Ronald } \\
2006\end{array}$ & $\begin{array}{l}\text { Prednisone } 60 \mathrm{mg} / \mathrm{m}^{2} \text { every other } \\
\text { day for } 3 \mathrm{months} \text {, then } 40 \mathrm{mg} / \mathrm{m}^{2} \\
\text { every other day for } 9 \text { months, } \\
\text { then } 30 \mathrm{mg} / \mathrm{m}^{2} \text { every other day } \\
\text { for } 12 \mathrm{months}\end{array}$ & Placebo & $\begin{array}{l}\text { Persistent severe proteinuria, } \\
(\mathrm{UP} / \mathrm{C}) \text { ratio }>1.0 \text { or moderate } \\
\text { proteinuria, i.e., UP/C ratio }>0.5 \text {. } \\
\text { Age }<40 \text { years; M:F } 26: 13\end{array}$ & 24 & 30 & 2 & 29 & 4 \\
\hline $\begin{array}{l}\text { Pozzi } \\
1999\end{array}$ & $\begin{array}{l}\text { Methylprednisolone } 1 \mathrm{~g} \text { i.v. for } 3 \\
\text { consecutive days, then prednisone } \\
0.5 \mathrm{mg} / \mathrm{kg} / \text { day for } 6 \text { months }\end{array}$ & $\begin{array}{l}\text { Supportive } \\
\text { therapy }\end{array}$ & $\begin{array}{l}\text { Age } 15-69 \text { years, urinary protein } \\
\text { excretion of } 1.0-3.5 \mathrm{~g} \text { daily for at } \\
\text { least } 3 \text { months, and plasma } \\
\text { creatinine concentrations } \\
\leq 133 \mathrm{~mol} / \mathrm{l}(1.5 \mathrm{mg} / \mathrm{dl})\end{array}$ & 60 & 43 & 10 & 43 & 23 \\
\hline $\begin{array}{l}\text { Shoji } \\
2000\end{array}$ & $\begin{array}{l}\text { Prednisolone } 0.8 \mathrm{mg} / \mathrm{kg} / \mathrm{day} \text { and } \\
\text { tapering to } 10 \mathrm{mg} \text { q.o.d. } 1 \text { year }\end{array}$ & $\begin{array}{l}\text { Dypiridamole } \\
300 \mathrm{mg} / \text { day }\end{array}$ & $\begin{array}{l}\text { Proteinuria less than } 1.5 \mathrm{~g} / \text { day; } \\
\text { plasma creatinine concentrations } \\
<1.5 \mathrm{mg} / \mathrm{dl} \text {. Age } 15 \text { and } 55 \text { years. }\end{array}$ & 12 & 11 & 0 & 8 & 0 \\
\hline $\begin{array}{l}\text { Kata- } \\
\text { fuchi } \\
2003\end{array}$ & $\begin{array}{l}\text { Prednisolone } 20 \mathrm{mg} / \text { day for } 1 \\
\text { month and tapering in } 18 \mathrm{months} \text {, } \\
\text { plus dypiridamole } 150-300 \mathrm{mg} / \text { day }\end{array}$ & $\begin{array}{l}\text { Dypiridamole } \\
150-300 \mathrm{mg} / \\
\text { day }\end{array}$ & $\begin{array}{l}\text { Plasma creatinine concentrations } \\
<1.5 \mathrm{mg} / \mathrm{dl} \text {. Age } 15 \text { and } 55 \text { years. } \\
\text { Age }<60 \text { years. }\end{array}$ & $65 \pm 25$ & 43 & 3 & 47 & 3 \\
\hline $\begin{array}{l}\text { Lai } \\
1986\end{array}$ & $\begin{array}{l}\text { Prednisolone } 40-60 \mathrm{mg} / \text { day for } \\
2 \text { months, then } 1 / 2 \text { dose in } \\
\text { subsequent } 2 \text { months }\end{array}$ & $\begin{array}{l}\text { Supportive } \\
\text { therapy }\end{array}$ & $\begin{array}{l}\text { IgA nephropathy with nephrotic } \\
\text { syndrome; age 11-59 years; M:F } \\
40: 35\end{array}$ & 38 & 17 & 2 & 17 & 3 \\
\hline $\begin{array}{l}\text { Julian } \\
1993\end{array}$ & $\begin{array}{l}\text { Alternate day prednisone } 60 \mathrm{mg} \\
3 \text { months }\end{array}$ & No treatment & $\begin{array}{l}\text { Creatinine clearance }>25 \mathrm{ml} / \mathrm{min} \\
\text { per } 1.73 \mathrm{~m}^{2}\end{array}$ & $6-24$ & 18 & 1 & 17 & 2 \\
\hline
\end{tabular}

$\mathrm{DRF}=$ Deteriorated renal function; $\mathrm{UH}=$ uremia and/or hemodialysis; $\mathrm{M}: \mathrm{F}=$ male:female.

Table 2. Quality assessment of RCTs included in the review

\begin{tabular}{|c|c|c|c|c|c|c|c|c|c|}
\hline \multirow[t]{2}{*}{ Reference } & \multicolumn{5}{|c|}{ Jadad score } & \multirow{2}{*}{$\begin{array}{l}\text { Sum of } \\
\text { Jadad } \\
\text { score }\end{array}$} & \multirow{2}{*}{$\begin{array}{l}\text { Lost at } \\
\text { follow-up }\end{array}$} & \multirow{2}{*}{$\begin{array}{l}\text { Intention } \\
\text { to treat } \\
\text { analysis }\end{array}$} & \multirow{2}{*}{$\begin{array}{l}\text { Allocation } \\
\text { concealment }\end{array}$} \\
\hline & $\begin{array}{l}\text { randomi- } \\
\text { zation }\end{array}$ & $\begin{array}{l}\text { appropriate- } \\
\text { ness of ran- } \\
\text { domization }\end{array}$ & $\begin{array}{l}\text { double } \\
\text { blind }\end{array}$ & $\begin{array}{l}\text { appropriate- } \\
\text { ness of } \\
\text { double blind }\end{array}$ & $\begin{array}{l}\text { analysis } \\
\text { reasons for } \\
\text { withdrawals }\end{array}$ & & & & \\
\hline Lv, 2009 & 1 & 1 & 0 & 0 & 1 & 3 & $8 / 72$ & no & unknown \\
\hline Ronald, 2006 & 1 & 1 & 1 & 1 & 1 & 5 & $6 / 59$ & yes & adequate \\
\hline Pozzi, 1999 & 1 & 1 & 0 & 0 & 1 & 3 & $3 / 86$ & yes & adequate \\
\hline Shoji, 2000 & 1 & 1 & 0 & 0 & 0 & 2 & $2 / 21$ & no & unknown \\
\hline Katafuchi, 2003 & 1 & 1 & 0 & 0 & 1 & 3 & $1 / 90$ & no & adequate \\
\hline Lai, 1986 & 1 & 0 & 0 & 0 & 1 & 2 & $0 / 34$ & no & unknown \\
\hline Julian, 1993 & 1 & 1 & 0 & 0 & 1 & 3 & $2 / 35$ & no & unknown \\
\hline
\end{tabular}




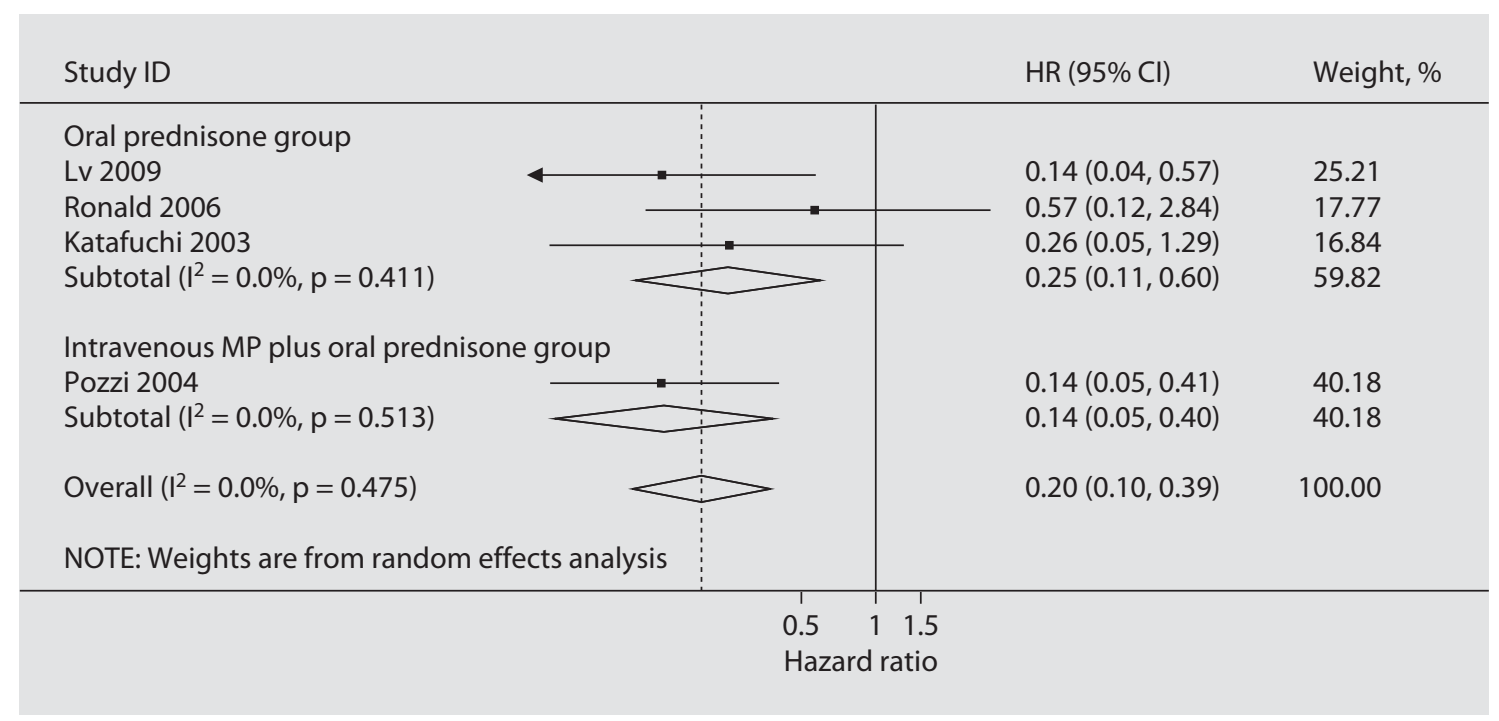

Fig. 2. Comparison of glucocorticoids versus controls on renal survival.

Table 3. Meta-analyses of age and creatinine clearance at baseline and mean systolic BP

\begin{tabular}{llllll}
\hline $\begin{array}{l}\text { Glucocorticoids } \\
\text { treatment vs. control group }\end{array}$ & $\begin{array}{l}\text { No. of } \\
\text { studies }\end{array}$ & $\begin{array}{l}\text { p for hetero- } \\
\text { geneity }^{\mathrm{a}}\end{array}$ & $\begin{array}{l}\text { Pooled } \\
\text { estimate }\end{array}$ & $\begin{array}{l}\text { 95\% Confidence } \\
\text { interval }\end{array}$ & $\begin{array}{l}\text { p for test for } \\
\text { overall effect }\end{array}$ \\
\hline $\begin{array}{l}\text { Age } \\
\begin{array}{l}\text { Creatinine clearance at baseline } \\
\text { Mean systolic BP (mmHg) }\end{array}\end{array}$ & 9 & 0.34 & 0.17 & -2.73 to 3.07 & 0.91 \\
$\quad$ Before treatment & 4 & 0.61 & -2.18 & -11.53 to 7.17 & 0.65 \\
$\quad$ After treatment & 4 & 0.26 & 1.82 & -2.45 to 6.08 & 0.47 \\
\hline
\end{tabular}

${ }^{\mathrm{a}}$ From Q test; ${ }^{\mathrm{b}}$ using fixed-effect model.

drawals were described in 6 trials, 3 studies met allocation concealment, and 2 studies met the intention-totreat analysis criteria.

\section{Effects on Mean Systolic Blood Pressure}

We conducted a meta-analysis of age, creatinine clearance at baseline and mean systolic blood pressure (BP) in the treated and controlled groups. No significant heterogeneity was found for outcomes among studies and between designs. Therefore, we combined these trials in a single meta-analysis by using a fixed-effect model. Results showed that age and creatinine clearance at baseline have no significant difference between treatment and control group (table 3). Glucocorticoids therapy signifi- cantly decreased mean systolic BP by a similar extent compared with the control group (table 3).

\section{Effects on Renal Survival}

Numbers of deterioration in renal function were reported in 6 studies. But only 4 RCTs reported renal survival data with Kaplan-Meier survival curves. Because the various steroid regimens employed may influence the results, we used subgroup analyses to decrease clinical heterogeneity. Subgroup analysis for oral prednisone treatment indicated that glucocorticoid treatment is beneficial for protecting renal function when compared with the control group ( 3 trials, HR $0.25,95 \%$ CI 0.11 to 0.60 , fig. 2); the same could be shown by subgroup analysis for 


\begin{tabular}{|c|c|c|c|c|c|c|c|}
\hline $\begin{array}{l}\text { Study } \\
\text { or subcategory }\end{array}$ & $\mathrm{N}$ & $\begin{array}{l}\text { Treatment } \\
\text { mean (SD) }\end{array}$ & $\mathrm{N}$ & $\begin{array}{l}\text { Control } \\
\text { mean (SD) }\end{array}$ & $\begin{array}{l}\text { SMD (fixed) } \\
95 \% \mathrm{Cl}\end{array}$ & $\begin{array}{l}\text { Weight } \\
\%\end{array}$ & $\begin{array}{l}\text { SMD (fixed) } \\
95 \% \mathrm{Cl}\end{array}$ \\
\hline Pozzi & 43 & $0.67(0.50)$ & 43 & $1.48(1.87)$ & - & 26.36 & $-0.59(-1.02,-0.15)$ \\
\hline Lv & 33 & $1.04(0.54)$ & 30 & $1.57(0.86)$ & - & 18.78 & $-0.74(-1.25,-0.22)$ \\
\hline Julian & 17 & $1.30(1.24)$ & 18 & $1.80(2.97)$ & - & 11.13 & $-0.21(-0.88,0.45)$ \\
\hline Katafuchi & 43 & $-0.84(1.78)$ & 47 & $-0.26(1.65)$ & - & 28.35 & $-0.34(-0.75,0.08)$ \\
\hline Lai & 17 & $2.30(2.20)$ & 17 & $3.30(3.10)$ & - & 10.69 & $-0.36(-1.04,0.32)$ \\
\hline Shoji & 11 & $0.29(0.23)$ & 8 & $0.71(0.39)$ & $\rightarrow$ & 4.69 & $-1.31(-2.33,-0.29)$ \\
\hline Total (95\% Cl) & 164 & & 163 & & 1 & 100.00 & $-0.51(-0.73,-0.29)$ \\
\hline \multicolumn{8}{|c|}{$\begin{array}{l}\text { Test for heterogeneity: } \chi^{2}=4.84, \text { d.f. }=5(p=0.44), I^{2}=0 \% \\
\text { Test for overall effect: } Z=4.52(p<0.00001)\end{array}$} \\
\hline & & & & Favou & $\begin{array}{l}-5 \quad 0 \\
\text { atment Fav }\end{array}$ & $\begin{array}{l}1 \\
10 \\
\text { ntrol }\end{array}$ & \\
\hline
\end{tabular}

Fig. 3. Comparison of glucocorticoids versus controls on daily proteinuria.

Table 4. Meta-analysis of patient adverse events and withdrawal

\begin{tabular}{|c|c|c|c|c|c|c|c|}
\hline & $\begin{array}{l}\text { No. of } \\
\text { studies }\end{array}$ & $\begin{array}{l}\text { Pred } \\
\text { group }\end{array}$ & $\begin{array}{l}\text { Control } \\
\text { group }\end{array}$ & $\begin{array}{l}\mathrm{p} \text { for hetero- } \\
\text { geneity }^{\mathrm{a}}\end{array}$ & $\begin{array}{l}\text { Pooled } \\
\text { estimate }^{b}\end{array}$ & $\begin{array}{l}\text { 95\% Confidence } \\
\text { interval }\end{array}$ & $\begin{array}{l}\mathrm{p} \text { for test for } \\
\text { overall effect }\end{array}$ \\
\hline $2 \mathrm{DM}$ & 5 & 1 & 0 & not applicable & 3 & 0.13 to 71.65 & 0.68 \\
\hline Hypertension & 5 & 16 & 28 & 0.45 & 0.73 & 0.37 to 1.46 & 0.38 \\
\hline Gastrointestinal tract (heartburn, bleeding) & 5 & 16 & 5 & 0.98 & 2.91 & 1.25 to 6.77 & 0.02 \\
\hline Insomnia, perspiration & 5 & 2 & 0 & 0.24 & 0.62 & -1.09 to 2.34 & 0.48 \\
\hline Cushingoid & 5 & 3 & 0 & not applicable & 7.0 & 0.39 to 125.99 & 0.19 \\
\hline Withdrawal & 6 & 7 & 7 & 0.37 & 0.88 & 0.33 to 2.34 & 0.26 \\
\hline
\end{tabular}

intravenous methylprednisolone plus oral prednisone treatment versus other nonimmunosuppressives (one trial, HR $0.14,95 \%$ CI 0.05 to 0.40 , fig. 2).

Overall, according to our meta-analysis, in which the weight of individual studies has been taken into account, in the remaining 4 studies, the hazard of deterioration in renal function was significantly reduced in the treatment groups (HR 0.20, 95\% CI 0.20 to 0.39), indicating that treatment with glucocorticoids had significant effects on renal survival when compared with the control group (fig. 2).

\section{Effects on Daily Proteinuria}

6 studies of 7 RCTs assessed daily proteinuria in a total of 327 patients, and 164 patients were assigned to the treatment groups, 163 patients were in the control group. Overall, according to this analysis, glucocorticoid treat- ment induced a greater reduction in proteinuria when compared with the control group (SMD, $-0.51 ; 95 \% \mathrm{CI}$, -0.73 to $-0.29, \mathrm{p}<0.0001$; heterogeneity $\chi^{2}=4.84 ; \mathrm{p}=$ 0.44 , fig. 3).

No heterogeneity of the effects was found, so univariate study-level meta-regression and subgroup analyses were not used for heterogeneity analysis.

\section{Adverse Effects of Treatment}

For glucocorticoid treatments versus control group, 5 studies [19-23] of 7 RCTs recorded adverse effects of treatment (table 4). Many adverse effects such as type 2 diabetes mellitus (2DM), hypertension, gastrointestinal tract reactions, Cushingoid, insomnia, and perspiration were reported in the treatment groups. The studies also reported that few patients withdrew from the study; in general, glucocorticoid agents were well tolerated in in- 


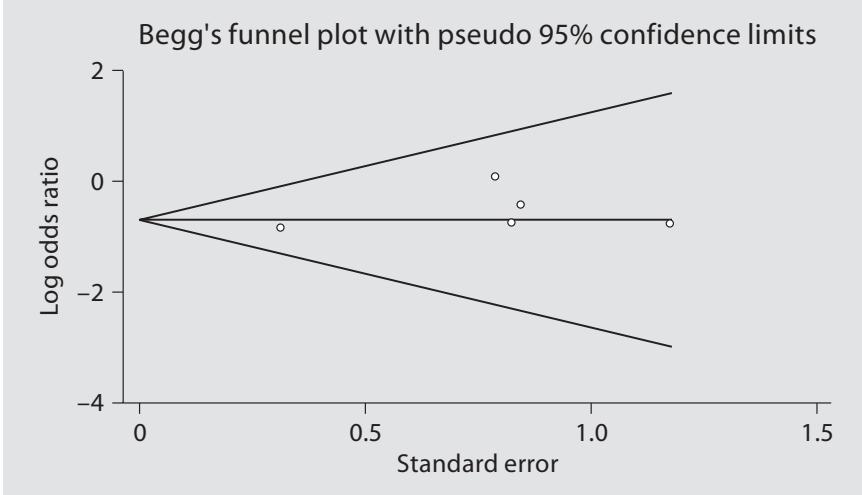

Fig. 4. Funnel plots of studies comparison glucocorticoids with controls on renal function.

cluded RCTs. Patients receiving steroid therapy had not an increased risk of developing 2DM, hypertension and Cushingoid adverse effects. There was a nonsignificant difference between the steroid and control groups (table 4). But the use of glucocorticoids was found to be associated with a significant increase in the risk of gastrointestinal tract adverse events (RR 2.91, 95\% CI 1.25 to $6.77, \mathrm{p}=0.02$; heterogeneity $\chi^{2}=1, \mathrm{p}=0.98$, table 4 ).

\section{Sensitivity Analysis and Publication Bias}

Our analyses were robust in both the choices of models and the statistical methods. The substitution of a random effects model for a fixed model did not change our initial qualitative interpretation of the pooled treatment effect on renal function and proteinuria. Likewise, removal of studies with Jadad scores $<3$ from our analysis did not alter the results for effects of glucocorticoid agents on renal function when compared with the control group and proteinuria. The Funnel plots and Begg's test applied to individual trials did not disclose any publication bias (95\% CI -0.94 to $2.20, \mathrm{p}=0.29$, fig. 4 ).

\section{Discussion}

IgA nephropathy is the most common glomerulonephritis worldwide, and no specific therapy has yet been defined because of the partially uncomprehended pathogenesis. Therapeutic approaches have been attempted in the last 20 years, and several studies have been published illustrating their results. Evidence-based recommendations for the management of IgAN were published since 1999 [25]. Most of the evidence-based recommendations are about immunosuppressive treatments for IgAN [2629]. Two of these recommendations commented on glucocorticoid agents for IgAN in protecting renal function and reducing proteinuria. However, the results are paradoxical, and these recommendations should be partly criticized for methodology. The main criticism of metaanalysis by Samuels et al. [27] was that they were based on a variety of sources, including non-randomized controlled trial data and quasi-randomized controlled trials. As we know, glucocorticoid agents therapy has major side effects, however, these recommendations did not evaluate the safety of glucocorticoid agents treatments for IgAN. More importantly, renal survival was data of time to events. The use of OR and RR to analyze survival data might be inappropriate [14]. The HR (hazard ratio) should be used instead as a summary estimator.

In this meta-analysis, we identified 7 RCTs that compared the glucocorticoids regimens with a control group. The meta-analysis showed that glucocorticoid agents had statistically significant effects in protecting renal function and reducing proteinuria in patients with IgAN when compared with the control group. This evidence is fairly straightforward in the majority of RCTs, even with their quality limitations and heterogeneity. It is to date widely accepted that cases of IgA nephropathy with minimal histological change respond highly to steroids, and these cases should be distinguished from IgA nephropathy with severe renal damage and nephrotic-range proteinuria. Meta-analysis confirms that steroids are effective on proteinuria in patients with IgA nephropathy with mild and moderate renal lesions. More important, we evaluated the safety of glucocorticoid agents for IgAN. In general, glucocorticoids were well tolerated, while they were associated with a significant increase in the risk of gastrointestinal tract adverse events.

Although our analysis provides recommendations for IgAN treatment, our meta-analysis had several limitations that should be considered. First, the quality of the individual controlled trials was not essentially high. Only 5 of 7 RCTs had a Jadad score $\geq 3$. Therefore, we conducted a quality assessment of the studies included, and clearly showed the details of each study. Many high-quality, well-designed trials should be used. Studies should have long enough follow-up time, and clearly report the numbers of patients who recovered, deteriorated, or had renal replacement therapy. Second, dose and type of drug, i.e. the agents used in the glucocorticoids treatment group, are different. At the same time, the primary endpoints of the studies are different. Because the study periods were not long enough to evaluate this slowly pro- 
gressive chronic disease, some studies did not assess the true outcome of renal death (defined as ESRD). Longterm follow-up studies that treat the true outcome might yield different results. Finally, most of the studies included patients who were receiving concomitant drugs, such as RAS blockers, beta-blocker, calcium channel blocker, or thiazide diuretics agents. Although we included this kind of studies with such concomitant drugs in the same way for both intervention and control groups, studies to assess the effect of glucocorticoid agents alone in patients who are not receiving other therapy are needed. Heterogeneity in this subset was high, but the small number of studies makes interpretation difficult.

In conclusion, glucocorticoid agents seem to be beneficial for both reducing proteinuria and stabilizing kidney function in patients with IgA nephropathy. Using glucocorticoids agents are a promising strategy and should be investigated further. Of course, we should be careful for its gastrointestinal tract adverse effects.

\section{References}

1 Berger J, Hinglais N: Les depots intercapillaires d'IgA-IgG. J Urol Nephrol 1968;74: 694-695.

2 D'Amico G: The commonest glomerulonephritis in the world: IgA nephropathy. Q J Med 1987;245:709-727.

-3 Julian BA, Waldo FB, Rifai A, Mestecky J: IgA nephropathy, the most common glomerulonephritis worldwide: a neglected disease in the United States? Am J Med 1988;84:129_ 132.

4 Levy M, Berger J: Worldwide perspective of IgA nephropathy. Am J Kidney Dis 1988;12: 340-347.

5 Schena FP: Immunoglobulin A nephropathy with mild renal lesions: a call in the forest for the physicians and nephrologists. Am J Med 2001;110:499-500.

-6 Rostoker G, Desvaux-Belghiti D, Pilatte Y, et al: Immunomodulation with low-dose immunoglobulins for moderate IgAN and $\mathrm{He}-$ noch-Schonlein purpura. Preliminary results of a prospective uncontrolled trial. Nephron 1995;69:327-334.

7 Samuels JA, Strippoli GF, Craig JC, et al: Immunosuppressive agents for treating IgA nephropathy. Cochrane Database Syst Rev 2003;CD003965.

-8 Barratt J, Feehally J: IgA nephropathy. J Am Soc Nephrol 2005;16:2088-2097.

-9 Floege J, Eitner F: Present and future therapy options in IgA nephropathy. J Nephrol 2005; 18:354-361

10 Juni P, Altman DG, Egger M: Systematic reviews in health care: assessing the quality of controlled clinical trials. BMJ 2001;323:4246.
Schulz KF, Chalmers I, Hayes RJ, et al: Empirical evidence of bias. Dimensions of methodological quality associated with estimates of treatment effects in controlled trials JAMA 1995;273:408-412.

12 Jadad AR, Moore RA, Carroll D, et al: Assessing the quality of reports of randomized clinical trials: is blinding necessary? Control Clin Trials 1996;17:1-12.

13 Palmer BF: Proteinuria as a therapeutic target in patients with chronic kidney disease. Am J Nephrol 2007;27:287-293.

14 Parmar MK, Torri V, Stewart L: Extracting summary statistics to perform meta-analyses of the published literature for survival end-points. Stat Med 1998;17:2815-2834.

15 Mantel N, Haenszel W: Statistical aspects of the analysis of data from retrospective studies of disease. J Natl Cancer Inst 1959;22: 719-748

16 Fleiss JL: Analysis of data from multiclinic trials. Control Clin Trials 1986;7:267-275.

17 DerSimonian R, Laird N: Meta-analysis in clinical trials. Control Clin Trials 1986;7: 177-188.

18 Lv J, Zhang H, Chen Y, et al: Combination therapy of prednisone and ACE inhibitor versus ACE-inhibitor therapy alone in patients with IgA nephropathy: a randomized controlled trial. Am J of Kidney Dis. 2009; 53(1):26-32.

19 Hogg RJ, Lee J, Nardelli N, et al: Clinical trial to evaluate omega-3 fatty acids and alternate day prednisone in patients with IgA nephropathy: report from the Southwest Pediatric Nephrology Study Group. Clin J Am Soc Nephrol. 2006;1:467-474.

-20 Julian BA, Barker C: Alternate day prednisone therapy in IgA nephropathy. Preliminary analysis of a prospective, randomized, controlled trial. Contrib Nephrol 1993;104: 198-206.
21 Lai KN, Lai FM, Ho CP, Chan KW: Corticosteroid therapy in IgA nephropathy with nephrotic syndrome: a long-term controlled trial. Clin Nephrol 1986;26:174-180.

22 Pozzi C, Bolasco PG, Fogazzi GB, et al: Corticosteroids in IgA nephropathy: a randomized controlled trial. Lancet 1999;353:883887.

23 Katafuchi R, Kiyoshi I, Mizumasa T, Tanaka $\mathrm{H}$, et al: Controlled, prospective trial of steroid treatment in IgA nephropathy: a limitation of low-dose prednisolone therapy. Am J Kidney Dis 2003;41:972-983.

24 Shoji T, Nakanishi I, Suzuki A, et al: Early treatment with corticosteroids ameliorates proteinuria, proliferative lesions and mesangial phenotypic modulation in adult diffuse proliferative IgA nephropathy. Am J Kidney Dis 2000;35:194-201.

25 Nolin L, Courteau M: Management of IgA nephropathy: evidence-based recommendations. Kidney Int 1999;70(suppl):S56-S62.

26 Strippoli GF, Manno C, Schena FP: An 'evidence-based' survey of therapeutic options for IgA nephropathy: assessment and criticism. Am J Kidney Dis 2003;41:1129-1139.

27 Samuels JA, Strippoli GF, Craig JC, et al: Immunosuppressive treatments for immunoglobulin A nephropathy: a meta-analysis of randomized controlled trials. Nephrology (Carlton) 2004;9:177-185.

28 Kawamura T: Treatment of IgA nephropathy: glucocorticoids, tonsillectomy, and mycophenolate mofetil. Contrib Nephrol 2007; 157:37-43.

29 Navaneethan SD, Viswanathan G, Strippoli GF: Meta-analysis of mycophenolate mofetil in IgA nephropathy. Nephrology (Carlton) 2008;13:90. 